\title{
Big Data and Data Analytics in Agricultural Space: Towards Sustainable and Intelligent Agro Sector Development
}

\author{
P. K. Paul ${ }^{\mathrm{I}}$, Anil Bhuimali ${ }^{2}$, R.R. Sinha ${ }^{3}$ K.S. Tiwary ${ }^{4}$, Pappachan Baby ${ }^{5}$ \\ R. Rajesh ${ }^{6}$
}

${ }^{\mathrm{I}}$ Executive Director, MCIS, Department of CIS, Information Scientist (Offg.), Raiganj University, India.

${ }^{2}$ Vice Chancellor, Raiganj University, West Bengal, India.

${ }^{3}$ Pro Vice Chancellor (Asian Region), Commonwealth Vocational

University, Kingdom of Tonga.

${ }^{4}$ Dean (Science \& ${ }^{3}$ Management), Raiganj University, West Bengal, India. ${ }^{5}$ Head (Asian Region), Ballsbridge University, Commonwealth of Dominica.

${ }^{6}$ Principal, Rohini College of Engineering and Technology (RCET),

Kanyakumari, TN, India.

\#pkpaul.infotech@gmail.com

\section{Abstract}

Agriculture has become important for each and everyone for its importance in the daily lives. Cultivation and farming is most important and valuable in our life as it is needed for all of us. Furthermore it is essential to have better healthy agricultural systems and in this context Agricultural Informatics play a leading role. Here proper mechanism is very important in healthy and modern agricultural systems and development and for this various initiatives and methods are useful and enhancing. There are rapid changes and growth in respect of the support of various technologies which help in modernizing agricultural production and systems like genetic engineering and technologies, computing 
and information technology, nano-science and technology, Management Science etc. The combination of Information Technology and Agricultural Sciences has led to the developed the Agricultural Informatics. Agricultural Informatics is simply IT applications in Agriculture and allied areas with its various components. Though in recent past more emerging technologies of IT are enhancing the traditional growth of the Agricultural Informatics and among the technologies important are Big Data and Analytics, AI \& Robotics, Cloud Computing \& Virtualization, Internet of Things etc. And among these, Big Data and Analytics is emerging and changing the entire arena of the Agricultural Informatics with its periphery and functioning. As the data is changing and rapidly growing therefore, Big Data and Analytics is the solution for managing data effectively with large amount and also the complex data. This paper is theoretical and various aspects of Agricultural Informatics are mentioned such as features, applications and specially the impact of Big Data and Analytics. The Paper is also focused on possibilities of Big Data and Analytics in Agricultural Informatics with challenges, issues etc.

Keywords: Agricultural Informatics, Agricultural Information Technology, Emerging Technologies, Big Data and Analytics, Data Science.

\section{Objectives:}

The present work 'Big Data and Data Analytics in Agricultural Space: Towards Sustainable and Intelligent 
This is a limited preview of the chapter.

To read the full-text chapter, get access by purchasing this chapter or consider buying the complete book. If your library has subscription to EBSCOhost, the chapter including other chapters of the book can be accessed through your library.

This chapter is a part of the book, 'Management of Data in AI Age' ISBN (paperback): 978-8I-948483-4־9; ISBN (ebook): 978-8I$948483-5-6$

Book DOI: https://dx.doi.org/Io.46679/isbn9788194848349 Chapter DOI: https://dx.doi.org/Io.46679/isbn9788I9484834905 
Analytics. Big Data is an emerging topic and it needs joint efforts from the various professional associations, societies, council, and government department and so on. Furthermore, ministries such as agriculture, Information Technology, education and human resources, social welfare can also take important imitative for the integration of the Big Data in Agricultural Systems and also other allied areas. Skilling, Training etc. are also important and valuable of big data in agriculture and allied areas for the solid, intelligent, sustainable agricultural development.

\section{References}

[1]. Abbasi, A. Z., Islam, N., छ Shaikh, Z. A. (2014). A review of wireless sensors and networks' applications in agriculture. Computer Standards E。 Interfaces, 36(2), 263-270.

[2]. Adão, T., Hruška, J., Pádua, L., Bessa, J., Peres, E., Morais, R., छ. Sousa, J. J. (20I7). Hyperspectral imaging: A review on UAV-based sensors, data processing and applications for agriculture and forestry. Remote Sensing, 9 (II), IIIO.

[3]. Adetunji, K. E., छə Joseph, M. K. (20I8, August). Development of a Cloud-based Monitoring System using 4duino: Applications in Agriculture. In 2018 International Conference on Advances in Big Data, Computing and Data Communication Systems (ic $A B C D$ ) (pp. 4849-4854). IEEE.

[4]. Ahmad, T., Ahmad, S., Eु Jamshed, M. (20I5, October). A knowledge based Indian agriculture: With cloud ERP arrangement. In 2015 International Conference on Green Computing and Internet of Things (ICGCIoT) (pp. 333-340). IEEE.

[5]. Aubert, B. A., Schroeder, A., छ Grimaudo, J. (20I2). IT as enabler of sustainable farming: An empirical analysis of farmers' adoption decision of precision agriculture technology. Decision support systems, 54(I), 510-520. 
[6]. Babu, S. M., Lakshmi, A. J., छ Rao, B. T. (2015, April). A study on cloud based Internet of Things: CloudIoT. In 2015 global conference on communication technologies (GCCT) (pp. 60-65). IEEE.

[7]. Balamurugan, S., Divyabharathi, N., Jayashruthi, K., Bowiya, M., Shermy, R. P., छ Shanker, R. (2016). Internet of agriculture: Applying IoT to improve food and farming technology. International Research Journal of Engineering and Technology (IRJET), 3(10), 713-719.

[8]. Bauckhage, C., \& Kersting, K. (2013). Data mining and pattern recognition in agriculture. KI-Künstliche Intelligenz, 27(4), 313324.

[9]. Channe, H., Kothari, S., छ Kadam, D. (2015). Multidisciplinary model for smart agriculture using internet-of-things (IoT), sensors, cloud-computing, mobile-computing $\&$ big-data analysis. Int. J. Computer Technology E A Applications, 6(3), 374-382.

[10]. Gill, S. S., Chana, I., छ Buyya, R. (20I7). IoT based agriculture as a cloud and big data service: the beginning of digital India. Journal of Organizational and End User Computing (JOEUC), $29(4), \mathrm{I}-23$.

[11]. Gómez-Chabla, R., Real-Avilés, K., Morán, C., Grijalva, P., छ Recalde, T. (20I9, January). IoT Applications in Agriculture: A Systematic Literature Review. In 2nd International Conference on ICTs in Agronomy and Environment (pp. 68-76). Springer, Cham.

[12]. Goraya, M. S., \& Kaur, H. (2015). Cloud computing in agriculture. HCTL Open International Journal of Technology Innovations and Research (IJTIR), I6, 2321-1814.

[13]. Guardo, E., Di Stefano, A., La Corte, A., Sapienza, M., छ Scatà, M. (20I8). A fog computing-based iot framework for precision agriculture. Journal of Internet Technology, I9(5), I4OI-I4II.

[14]. Kamble, S. S., Gunasekaran, A., छ Gawankar, S. A. (2020). Achieving sustainable performance in a data-driven agriculture supply chain: A review for research and applications.

International Journal of Production Economics, 219, 179-194. 
[15]. Kajol, R., छ Akshay, K. K. (20I8). Automated Agricultural Field Analysis and Monitoring System Using IOT. International Journal of Information Engineering and Electronic Business, II (2), I7.

[16]. Khattab, A., Abdelgawad, A., छ Yelmarthi, K. (20ı6, December). Design and implementation of a cloud-based IoT scheme for precision agriculture. In 201628 th International Conference on Microelectronics (ICM) (pp. 20I-204). IEEE.

[17]. Liu, S., Guo, L., Webb, H., Ya, X., छ Chang, X. (2019). Internet of Things monitoring system of modern eco-agriculture based on cloud computing. IEEE Access, 7, 37050-37058.

[18]. Manos, B., Polman, N., छ Viaggi, D. (20II). Agricultural and environmental informatics, governance and management: Emerging research applications. Z. Andreopoulou (Ed.). IGI Global (70I E. Chocolate Avenue, Hershey, Pennsylvania, I7033, USA).

[19]. Muangprathub, J., Boonnam, N., Kajornkasirat, S., Lekbangpong, N., Wanichsombat, A., \& Nillaor, P. (20I9). IoT and agriculture data analysis for smart farm. Computers and electronics in agriculture, $156,467-474$.

[20]. Na, A., छ Isaac, W. (20I6, January). Developing a humancentric agricultural model in the IoT environment. In 2016 International Conference on Internet of Things and Applications (IOTA) (pp. 292-297). IEEE.

[21]. Nandyala, C. S., छ Kim, H. K. (20I6). Green IoT agriculture and healthcare application (GAHA). International Journal of Smart Home, IO(4), 289-300.

[22]. Nayyar, A., छ Puri, V. (2016). Smart farming: IoT based smart sensors agriculture stick for live temperature and moisture monitoring using Arduino, cloud computing $छ$ solar technology. In Proc. of The International Conference on Communication and Computing Systems (ICCCS-20I6) (pp. 9781315364094-I2I).

[23]. Ojha, T., Misra, S., E Raghuwanshi, N. S. (2015). Wireless sensor networks for agriculture: The state-of-the-art in practice and future challenges. Computers and Electronics in Agriculture, II $8,66-84$. 
[24]. Othman, M. F., E̋ Shazali, K. (20I2). Wireless sensor network applications: A study in environment monitoring system. Procedia Engineering, 4I, I204-I210.

[25]. Ozdogan, B., Gacar, A., \& Aktas, H. (20I7). Digital agriculture practices in the context of agriculture 4.o. Journal of Economics Finance and Accounting, 4(2), I86-193.

[26]. Paur, Prantosh Kumar Minakshi Ghosh, Dipak Chaterjee. (20I4)Information Systems \& Networks (ISN): Emphasizing Agricultural Information Networks with a case Study of AGRIS.Scholars Journal of Agriculture and Veterinary Sciences. I (I).

[27]. Paul, Prantosh Kumar (20I3) Information and Knowledge Requirement for Farming and Agriculture Domain.International Journal of Soft Computing Bio Informatics4 (2), 80-84

[28]. Paul, Prantosh Kumar et.al. (2015) Agricultural Problems in India requiring solution through Agricultural Information Systems: Problems and Prospects in Developing Countries. International Journal of Information Science and Computing 2 (I), 33-40

[29]. Paul, Prantosh Kumar et.al. (20I6). Cloud Computing and Virtualization in Agricultural Space: A Knowledge Survey. Palgo Journal of Agriculture, 4(2), 202-206

[30]. Paul, Prantosh Kumar et.al. (2015). Information and Communication Technology and Information: their role in Tea Cultivation and Marketing in the context of Developing Countries-A Theoretical Approach. Current Trends in Biotechnology and Chemical Research. 5 (2), I55-16I

[31]. Rezník, T., Charvát, K., Lukas, V., Charvát Jr, K., Horáková, Š., छ઼ Kepka, M. (2015, September). Open data model for (precision) agriculture applications and agricultural pollution monitoring. In EnviroInfo and ICT for Sustainability 2015. Atlantis Press.

[32]. TongKe, F. (20I3). Smart agriculture based on cloud computing and IOT. Journal of Convergence Information Technology, 8(2).

[33]. Tsekouropoulos, G., Andreopoulou, Z., Koliouska, C., Koutroumanidis, T., छ Batzios, C. (20I3). Internet functions in 
marketing: multicriteria ranking of agricultural SMEs websites in Greece. Agrárinformatika/journal of agricultural informatics, 4(2), 22-36.

[34]. Zamora-Izquierdo, M. A., Santa, J., Martínez, J. A., Martínez, V., छ Skarmeta, A. F. (2019). Smart farming IoT platform based on edge and cloud computing. Biosystems engineering, I77, 4-I7. 